\section{Pengaruh Kualitas Perangkat Desa Terhadap Kualitas Laporan Keuangan Desa}

\author{
Quality of \\ Village Financal \\ Report
}

\author{
Agus Wahyudi dan Diah Anggeraini Hasri \\ Program Studi Akuntansi, Universitas Teknologi Sumbawa, Indonesia \\ E-Mail : agus.wahyudi@uts.ac.id
}

293

Submitted: FEBRUARI 2021

Accepted: JULI 2021

\begin{abstract}
This study aims to examine the effect of the quality of village officials on the quality of village financial reports at the village government in Utan District, Sumbawa Regency. This type of research is quantitative research with an associative approach. The data collection technique is using a questionnaire. The number of samples in this study amounted to 36 respondents consisting of the village head, the head of the village consultative body, the village secretary, and the village treasurer. The results showed that the quality of village officials had a positive and significant effect on the quality of village financial reports, with the existence of quality village officials it would produce quality financial reports. The results of the determination test showed that $58.2 \%$ of the village financial report quality variables could be explained by the village apparatus quality variable, the rest was influenced by other variables that were not included in this study.
\end{abstract}

Keywords: Quality of Village Apparatus, Quality of Village Financial Reports, Village Government

\begin{abstract}
ABSTRAK
Penelitian ini bertujuan untuk menguji pengaruh kualitas perangkat desa terhadap kualitas laporan keuangan desa pada pemerintah desa di Kecamatan Utan Kabupaten Sumbawa. Jenis penelitian ialah penelitian kuantitatif dengan pendekatan asosiatif. Teknik pengumpulan data yakni menggunaka kuesioner. Jumlah sampel dalam penelitian ini berjumlah 36 responden yang terdiri dari kepala desa, ketua badan permusyawaratan desa, sekretaris desa, dan bendahara desa. Hasil penelitian menunjukkan bahwa kualitas perangkat desa berpengaruh positif dan signifikan terhadap kualitas laporan keuangan desa, dengan adanya perangkat desa yang berkualitas maka akan menghasilkan laporan keuangan yang berkualitas. Hasil uji determinasi menunjukkan bahwa 58,2\% variabel kualitas laporan keuangan desa dapat dijelaskan oleh variabel kualitas perangkat desa, sisanya dipengaruhi oleh variabel lain yang tidak diikut sertakan dalam penelitian ini.
\end{abstract}

Kata Kunci: kualitas perangkat desa, kualitas laporan keuangan desa, pemerintah desa

\section{PENDAHULUAN}

Pemerintah desa sejak diterbitkannya Undang-Undang Nomor 6 Tahun 2014 tentang desa menuntut pemerintah desa untuk selalu transparan, akuntabel, partisipatif serta dilakukan dengan tertib dan disiplin anggaran. Salah satu upaya untuk mewujudkan pemerintah desa yang bersih maka pemerintah desa diwajibkan untuk menyusun laporan keuangan desa. Adanya laporan keuangan yang berkualitas dapat memberikan manfaat dalam upaya mengambil kebijakan suatu pemerintah di masa yang akan mendatang (Pujanira dan Taman, 2017).

Fenomena kualitas laporan keuangan pemerintah di Indonesia merupaka sesuatu hal yang menarik untuk dikaji lebih lanjut. Dasar pemikiran ini berasal dari fakta bahwa terdapat penyimpangan yang berhasil ditemukan oleh Pemerintah Daerah Kabupaten

\section{JIAKES}

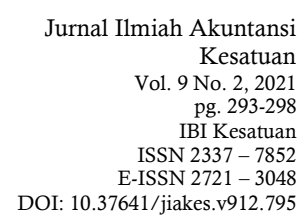

Jurnal Ilmiah Akuntansi Kesatuan Vol. 9 No. 2, 2021 pg. 293-298 ISSN $2337-7852$ ISSN $2337-7852$
E-ISSN $2721-3048$ DOI: $10.37641 /$ jiakes.v912.795 
Quality of Village Financial Report

294
Sumbawa yakni adanya fenomena yang terjadi di Kabupaten Sumbawa yakni penyimpangan dalam pengelolaan dana desa, sehingga pemerintah mengambil sikap memberhentikannya secara permanen. Satu Kades di Kecamatan Utan Dipecat sebanyak satu oknum Kepala Desa (Kades) di Kecamatan Utan tepatnya Desa Tengah resmi diberhentikan secara definitif, sesuai Surat Keputusan Bupati Sumbawa. Setelah sebelumnya satu oknum Kades ini telah diberlakukan pemberhentian sementara dan diminta menyelesaikan kewajibannya (www.pulausumbawanews.net, 2019). Adanya kasus ini mempengaruhi tingkat kualitas laporan keuangan desa sehingga perlu diperbaiki, salah satunya peningkatan kualitas perangkat desa sebagai pihak yang diberikan amanah dalam mengelola keuangan desa.

Terbentuknya laporan keuangan desa yang berkualitas didukung dengan adanya perangkat desa yang berkualitas. Dalam mencapai tujuan yang telah ditetapkan, perangkat desa sebagai penggerak jalannya organisasi sangatlah diperlukan. Agar terdapat perangkat desa yang berkualitas perlu adanya manajemen sumber daya manusia. Pemerintah desa sangat membutuhkan perangkat desa yang profesioanl dengan memiliki wawasan yang luas, kompeten dalam bidangnya, dan memiliki jiwa kompetisi yang sportif (Oktarina, et al, 2016). Penyusunan laporan keuangan yang berkualitas membutuhkan perangkat desa yang kompeten dan memahami aturan penyusunan laporan keuangan baik yang dikeluarkan oleh pemerintah pusat hingga pemerintah daerah (Kiranayanti dan Erawati, 2016)

Perangkat desa merupan faktor penting dalam terciptanya laporan keuangan yang berkualitas. Perangkat desa perlu untuk merencanakan, melaksanakan, dan mengendalikan entitas yang bersangkutan dalam mengelola keuangan desa. untuk mengelola keuangan tersebut, maka perangkat desa perlu memiliki keterampilan, pengetahuan, dan kemampuan yang dimilikinya dalam hal menyelesaikan tugas-tugas yang dibebankannya (Wati, et al, 2014). Beranjak dari hal tersebut penelitian ini bertujuan untuk menguji pengaruh kualitas perangkat desa terhadap kualitas laporan keuangan desa pada pemerintah desa di Kecamatan Utan Kabupaten Sumbawa.

\section{Pengembangan Hipotesis}

Kualitas Laporan Keuangan Desa. Berdasarkan Peraturan Pemerintah Nomor 71 Tahun 2010, laporan keuangan pemerintah yang berkualitas perlu memperhatikan tingkat keandalan, relevan, dapat dipahami, dan dapat digunakan. Kualitas laporan keuangan dapat dikatak baik maka seluruh informasi yang disajikan dalam laporan keuangan tersebut perlu memperhatikan kriteria tersebut, di mana pemerintah desa perlu memperhatikan pedoman pengelolaan keuangan desa seperti yang tertuang dalam Peraturan Bupati Sumbawa Nomor 14 Tahun 2017. Pemerintah desa perlu membuat laporan semester pertama dan semester terakhir serta membuat laporan pertanggungjawaban realisasis pengguaan Anggaran Pendapatan dan Belanja Desa (APBDes).

Kualitas Perangkat Desa. Perangkat desa yang berkualitas perlu memiliki kemampuan untuk melaksanakan fungsi-fungsi atau kewenangannya untuk mencapai tujuan secara efektif dan efisien. Kualitas perangkat desa merupakan kemampuan perangkat desa untuk melaksanakan tugas dan tanggung jawab yang diberikan kepadanya dengan bekal pendidikan, pelatihan, dan pengalaman yang cukup memadai. Perangkat desa yang memilik pemahaman yang tinggi terhadap tugas dan fungsinya, serta hambatan yang ditemukan dalam pengolahan data juga berdampak pada penyajian laporan keuangan.

Hubungan Kualitas Perangkat Desa dan Kualitas Laporan Keuangan Desa. Kualitas perangkat desa merupakan kemampuan perangkat desa untuk melaksanakan fungsi-fungsi atau kewenangannya untuk mencapai tujuannya secara efektif dan efisien. Hasil penelitian yang dilakukan oleh Wati, et al (2014) menunjukkan dengan adanya sumber daya manusia yang kompten maka akan menghasilkal laporan keuangan yang berkualitas. Perangkat desa perlu memiliki kompetensi, maka peranan dalam dalam merencanakan, melaksanakan, dan mengendalikan organisasi akan berjalan dengan baik. 
Jika perangkat desa yang dimiliki oleh pemerintah desa berkualitas maka kualitas laporan keuangan desa akan meningkat, sehingga laporan keuangan yang baik dapat memenuhi karakteristik kualitatif yakni andal, relevan, dapat dipahami, dan dapat digunakan. Sehingga dari hal tersebut peneliti menarik hipotesis yakni:

H1 : Kualitas Perangkat Desa Berpengaruh Terhadap Kualitas Laporan Keuangan Desa

\section{METODE PENELITIAN}

Penelitian ini merupakan penelitian kuantitatif dengan pendekatan asosiatif. Penelitian ini dilakukan pada desa-desa yang berada di wilayah Kecamatan Utana Kabupaten Sumbawa yang berjumlah 9 desa yakni Desa Bale Berang, Desa Jorok, Desa Labuhan Bajo, Desa Motong, Desa Orong Bawa, Desa Pukat, Desa Sabedo, Desa Stowe Brang, dan Desa Tengah. Dalam menentukan sampel penelitian menggunakan purposive sampling dengan kriteria yakni pihak-pihak yang terlibat dalam pengelolaan keuangan desa sehingga totalnya 36 responden yang terdiri dari kepala desa, ketua badan permusyawaratan desa, sekretaris desa, dan bendahara desa. Adapun teknik pengumpulan data menggunakan kuesioner. Teknik analisis data menggunakan aplikasi Statistikal Package for the Social Sciens (SPSS) meliputi uji kualitas data, uji asumsi klasik, analisis regresi linier Sederhana, uji determinasi, uji kelayakan model, dan uji hipotesis.

\section{HASIL DAN PEMBAHASAN \\ Uji Kualitas Data}

Uji kualitas data meliputi uji validitas dan reliabilitas. Hasil uji validitas menunjukkan bahwa seluruh butir pernyataan valid, hal ini dikarenakan nilai $r$ hitung lebih dari $r$ tabel yakni $r$ hitung lebih dari 0,3202. Kemudian hasil uji reliabilitas menunjukkab bahwa variabel kualitas perangkat desa dan kualitas laporan keuangan dinyatakan reliabel, karena nilai cronbach alpha lebih dari 0,70.

\section{Uji Asumsi Klasik}

Hasil uji asumsi klasik menunjukkan bahwa data terdistribusi normal, hal ini dikarenakan nilai signifikansi pada uji one-sample kolmogrov smirnov yakni 0,213 lebih dari 0,05 . Kemudian, berdasarkan uji rank spearman menunjukkan bahwa variabel yang digunakan oleh peneliti bebas dari masalah heteroskedastisitas karena nilai signifikansi lebih dari 0,05 . Kemudian hasil uji multikolonieritas menunjukkan bahwa variabel yang digunakan dalam penelitian ini bebas dari masalah multikolonieritas, hal ini dibuktikan dengan nilai toleransi lebih dari 0,1 dan nilai VIF kurang dari 10.

\section{Analisis Regresi Linier Berganda}

Dibawah ini disajikan persamaan regresi:

$$
\mathrm{KLK}=6,757+0,724 \mathrm{KPD}+\mathrm{E}
$$

Persamaan tersebut menunjukkan jika kualitas perangkat desa dianggap konstan, perubahan kualitas laporan keuangan desa sebesar 6,757. Jika variabel kualitas perangkat desa naik sebesar satu satuan, maka akan meningkatkan nilai variabel kualitas laporan keuangan desa sebesar 0,724 .

\section{Uji Determinasi}

Hasil uji determinasi dapat dilihat pada tabel dibawah ini

Tabel 1. Hasil Uji Determinasi

\begin{tabular}{cc}
\hline Keterangan & Nilai \\
\hline Adjusted $R$ Square & 0,582 \\
\hline Sumber: Hasil Ouput SPSS $(2021)$
\end{tabular}

Berdasarkan tabel diatas, dapat diketahui bahwa nilai Adjusted $R$ Square yakni 0,582. Hal ini menunjukkan sebanyak $58,2 \%$ variabel kualitas laporan keuangan desa dapat dijelaskan oleh variabel kualitas perangkat desa. kemudian sisanya 41,8\% dijelaskan oleh variabel lain yang tidak diikut sertakan dalam penelitian ini. 
Quality of

Village Financial

Report

\section{Uji Kelayakan Model}

Berdasarkan pengujian anova pada penelitian ini, menunjukkan bahwa model regresi layak dilanjutkan pada tahap pengujian selanjutnya. Hal ini dikarenakan nilai signifikansinya kurang dari 0,05 kemudian nilai F sebesar 49,656 lebih dari 4 .

\section{Uji Hipotesis}

Dibawah ini disajikan hasil uji hipotesis.

Tabel 2. Hasil Uji Hipotesis

\begin{tabular}{cccc}
\hline Variabel & Nilai t hitung & Nilai Signifikansi & Keputusan \\
\hline Kualitas Perangkat Desa & 7,047 & 0,000 & Hipotesis Diterima \\
\hline
\end{tabular}

Sumber: Hasil Ouput SPSS (2021)

Berdasarkan tabel diatas, dapat dilihat bahwa variabel kualitas perangkat desa berpengaruh terhadap kualitas laporan keuangan desa. hal ini dikarenakan nilai t hitung lebih dari t tabel yakni 7,047 > 2,0322 kemudian nilai signifikansinya kurang dari 0,05. Sehingga hipotesis diterima.

\section{Pembahasan}

\section{Kualitas Perangkat Desa Berpengaruh Terhadap Kualitas Laporan Keuangan Desa}

Berdasarkan hasil uji hipotesis menunjukkan bahwa perangkat desa berpengaruh positif dan signifikansi terhadap kualitas laporan keuangan desa. hal ini menunjukkan bahwa semakin berkualitas perangkat desa di wilayah Kecamatan Utan Kabupaten Sumbawa maka laporan keuangan desa yang dihasilkan semakin berkualitas. Di mana kualitas perangkat desa merupakan kemampuan yang dimiliki oleh perangkat desa berhubungan dengan pengetahuan, keterampilan, dan sikap dalam menyelesaikan pekerjaannya secara efisien dan efektif. Adanya perangkat desa yang berkualitas akan mendukung ketepatan waktu pembuatan laporan keuangan

Selaras dengan hasil penelitian Wati, et al (2014); Kiranayanti dan Erawati (2016); Pujanira dan Taman (2017); di mana dengan adanya sumber daya manusia yang berkompeten maka laporan keuangan yang dihasilkan akan berkualitas, sehingga laporan keuangan yang dihasilkan dapat memenuhi karakteristik kualitatif laporan keuangan. Jadi dengan adanya perangkat desa yang berkualitas dapat diketahui apakah suatu pemerintahan telah melaksanakan tugas dan fungsinya secara professional, efektif, dan efisien. Sehingga dengan adanya perangkat desa yang berkualitas dapat mendorong terwujudnya laporan keuangan yang berkualitas yang bebas dari salah saji material dan pengertian yang menyesatkan.

\section{PENUTUP}

Berdasarkan hasil penelitian dan pembahasan yang telah dilakukan, maka dapat ditarik simpulan bahwa kualitas perangkat desa berpengaruh positif dan signifikan terhadap kualitas laporan keuangan desa. Artinya, semakin berkualitas perangkat desa di wilayah Kecamatan Utan Kabupaten Sumbawa maka laporan keuangan desa yang dihasilkan semakin berkualitas.

Atas dasar simpulan di atas dan hasil penelitian serta pembahasan yang telah dilakukan, maka penulis mencoba untuk memberikan rekomendasi bagi peneliti selanjutnya sebagai berikut:

1. Pada uji determinasi, sebanyak $58,2 \%$ variabel keualitas laporan keuangan desa dapat dijelaskan oleh kualitas perangkat desa. Sehingg peneliti selanjutnya dapat menambahkan variabel lain yang tidak di ikut sertakan dalam penelitian ini misalnya sistem pengendalian internal, penerapan standar akuntansi pemerintahan, good governance, dan variabel lainya.

2. Bagi peneliti selanjutnya dapat memperluas area penelitian, sehingga tidak hanya berfokus pada pemerintah desa Kecamatan Utan Kabupaten Sumbawa, serta dapat memperluas area responden seperti menambahan kepala seksi yang ada di desa. 
DAFTAR PUSTAKA

Amwila, A.Y., Gendalasari, G.G. and Pratomo, A.W., 2020. Pelatihan Motivasi Menjelang Pensiun Bagi Aparat Sipil Negara (ASN) Kementrian Kehutanan. Jurnal Abdimas, 4(3), pp.241-250.

Aziz, M.L. and Sulistiono, S., 2020. Pengaruh Sikap Konsumen, Periklanan, dan Brand Image Terhadap Minat Beli Konsumen The Jungleland Adventure Theme Park. Jurnal Ilmiah Pariwisata Kesatuan, 1(1), pp.43-52.

Chairunnisa, F. and Pamungkas, B., 2020. Designing a Risk-Based Review Plan for Accrual Based Local Government Financial Reports. AFEBI Accounting Review, 5(01), pp.16-30.

Gendalasari, G.G., 2020. Pembinaan Organisasi Sosial Kemasyarakatan Mengenai Dampak Pandemi Covid-19 Terhadap Budaya Organisasi di Kecamatan Tamansari Kabupaten Bogor. Jurnal Abdimas Dedikasi Kesatuan, 1(2), pp.201-214.

Kartika, A. and Nuraini, A., 2020. Penerapan Penyajian Laporan Keuangan Berdasarkan SAK-ETAP Untuk Mengetahui Kinerja Keuangan UMKM Toko Angka Wijaya. Jurnal Abdimas Dedikasi Kesatuan, 1(1), pp.11-20.

Kiranayanti, I. A. E., \& Erawati, N. M. A. 2016. Pengaruh Sumber Daya Manusia, Sistem Pengendalian Intern, Pemahaman Basis Akrual Terhadap Kualitas Laporan Keuangan Daerah. E-Jurnal Akuntansi Universitas Udayana, 16(2), 1290-1318.

Mulyana, M., 2012. Consumer Behaviour: Sukses Dengan Memahami Konsumen.

Nuraini, A., 2020. Pencatatan Dan Pengaturan Keuangan Bisnis Usaha Mikro, Kecil Dan Menegah. Jurnal Abdimas, 4(2), pp.101-110.

Oktarina, M., Raharjo, K., \& Andini, R. 2016. Pengaruh penerapan standar akuntansi pemerintahan, kualitas aparatur pemerintah daerah dan good governance terhadap kualitas laporan keuangan Di Kota Semarang (Studi Kasus Pada Dinas Pengelolaan Keuangan Aset Daerah Kota Semarang Tahun 2014). Journal of Accounting, 2(2).

Pamungkas, B., Avrian, C. and Ibtida, R., 2019. Factors influencing audit findings of the Indonesian district governments' financial statements. Cogent Business \& Management, 6(1), p.1673102.

Pamungkas, B. and Afrianti, V., 2006. Evaluasi Akuntansi Pertanggungjawaban sebagai Alat Bantu Manajemen dalam Pengendalian Biaya: Studi Kasus pada PT. Cahaya Buana Intitama. Jurnal Ilmiah Ranggagading (JIR), 6(1), pp.7-13.

Paomey, Jifvy Magdalena Dina, and Bambang Pamungkas. "Improving Quality of Information On Local Financial Statements and Its Utilization for Capital Expenditure Budgeting (Case Study at The Provincial Government of East Nusa Tenggara)." In 3rd Asia-Pacific Research in Social Sciences and Humanities Universitas Indonesia Conference (APRISH 2018), pp. 101-118. Atlantis Press, 2019.

Pemerintah Kabupaten Sumbawa. 2017. Peraturan Bupati Sumbawa Nomor 14 Tahun 2017 tentang Perubahan Kedua Atas Peraturan Bupati Sumbawa Nomor 12 Tahun 2015 tentang Pedoman Pengelolaan Keuangan Desa. Sumbawa: Sekretaris Daerah Kabupaten Sumbawa.

Pemerintah Indonesia. 2010. Peraturan Pemerintah Republik Indonesia Nomor 71 Tahun 2010 tentang Standar Akuntansi Pemerintah. Lembaran Negara RI Tahun 2010, No. 123. Jakarta: Sekretariat Negara.

Pemerintah Indonesia. 2014. Undang-Undang Nomor 6 Tahun 2014 tentang Desa. Lembaran Negara RI Tahun 2014, No. 7. Jakarta: Sekretariat Negara.

Pujanira, P., \& Taman, A. 2017. Pengaruh kompetensi sumber daya manusia, penerapan standar akuntansi pemerintahan, dan penerapan sistem akuntansi keuangan daerah terhadap kualitas laporan keuangan pemerintah daerah provinsi diy. Nominal: Barometer Riset Akuntansi dan Manajemen, 6(2), 14-28.

Pulausumbawanews.net. 2019. Kasus Dana Desa, Tiga Kades di Sumbawa Dipecat. https://pulausumbawanews.net/2019/04/09/kasus-dana-desa-tiga-kades-disumbawa-dipecat/. (diakses pada tanggal 7 Desember 2020).
Quality of

Village Financial

Report

297 
Quality of Village Financial Report

298
Purba, J.H.V., 2020. Does Chinese Vegetable Oil Consumption Have Positive Implications for the Indonesia-China Trade Balance. Integrated Journal of Business and Economics, 4(1), pp.36-44.

Pratiwi, Y. and Pamungkas, B., 2014. Analisis Pengakuan Pendapatan, Belanja, dan Pembiayaan Daerah Pada Pemerintah Daerah Kota Bogor. Jurnal Ilmiah Akuntansi Kesatuan, 2(1), pp.059-072.

Purnama, D., Muharam, H. and Purba, J.H.V., 2018. HUBUNGAN ANTARA KUALITAS PELAYANAN DAN PERSONAL SELLING DENGAN KEPUASAN NASABAH BANK MANDIRI CABANG CISARUA. Economicus, 12(2), pp.101-112.

Retna, D.W. and Sulistiono, A., 2014. PENGARUH KUALITAS PRODUK DAN KUALITAS PELAYANAN TERHADAP KEPUASAN PELANGGAN. Jurnal Ilmiah Manajemen Kesatuan, 2(3).

Setiawan, B. and Fadillah, A., 2020. Pendampingan Penerapan Strategi Promosi Berbasis Digital Bagi UMKM Di Wilayah Kota Bogor. Jurnal Abdimas Dedikasi Kesatuan, 1(1), pp.29-36.

Wati, K. D., Herawati, N. T., AK, S., \& SINARWATI, N. K. (2014). Pengaruh Kompetensi SDM, Penerapan SAP, dan Sistem Akuntansi Keuangan Daerah Terhadap Kualitas Laporan Keuangan Daerah. JIMAT (Jurnal Ilmiah Mahasiswa Akuntansi) Undiksha, 2(1). 